\title{
Analisis Faktor Kepuasan Pasien BPJS JKRA dengan Kinerja Perawat di Rawat Inap Rumah Sakit Umum Daerah Meuraxa Kota Banda Aceh
}

\author{
Analysis of JKRA BPJS Patient Satisfaction Factors With Nurse \\ PerformanceInpatient Regional General Hospital Meuraxa, Banda Aceh City \\ Fauziah Andika*1, Anisa Astuti ${ }^{2}$ \\ ${ }^{1,2}$ Program Studi Ilmu Kesehatan Masyarakat, Universitas Ubudiyah Indonesia, Jalan Alue Naga, Desa Tibang, Kota Banda \\ Aceh, Indonesia \\ *Korespondensi Penulis: fauziah@uui.ac.id
}

\begin{abstract}
Abstrak
Berdasarkan observasi awal yang dilakukan di rawat inap kelas III RSUD Meuraxa sebagai penerima jasa pelayanan kesehatan BPJS JKRA, keluarga peserta mengeluh kurang puas dengan pelayanan kesehatan yang diterimanya. Mereka menganggap bahwa pasien yang menjadi peserta BPJS JKRA mendapat pelayanan dan perlakuan yang berbeda dengan pasien lain.Penelitian ini dilakukan untuk mengetahui hubungan tingkat kepuasan pasien BPJS JKRA dengan kinerja perawat di rawat inap Rumah Sakit Umum Daerah Meuraxa Kota Banda Aceh. Penelitian ini bersifat deskriptif analitik, dengan total sampel 100 pasien. Teknik pengambilan sampel adalah accidental sampling. Penelitian ini dilakukan pada tanggal 7 Mei sampai dengan 12 Mei 2018. Cara pengumpulan data dengan cara membagikan kuisioner. Hasil penelitian menunjukkan kepuasan pasien BPJS JKRA menurut aspek Bukti fisik didapatkan $p$ value 0,023 , kehandalan $p$ value 0,000 , kepedulian $p$ value 0,055 , empati $p$ value 0,003, jaminan $\mathrm{p}$ value 0,035 dengan kinerja perawat di rawat inap Rumah Sakit Umum Daerah Meuraxa Kota Banda Aceh. Dapat disimpulkan bahwa terdapat hubungan yang signifikan antara kepuasan pasien BPJS JKRA menurut aspek bukti fisik, kehandalan, empati, jaminan dengan kinerja perawat di rawat inap RSUD Meuraxa Kota Banda Aceh. Dan tidak terdapat hubungan kepuasan pasien BPJS JKRA menurut aspek kepedulian dengan kinerja perawat di rawat inap RSUD Meuraxa Kota Banda Aceh.
\end{abstract}

Kata kunci : kepuasan pasien, kinerja perawat, BPJS JKRA

\begin{abstract}
Based on preliminary observation conducted at third class III hospitalizationof Meuraxa Hospital as recipient of health service BPJS JKRA, the participant family complained less satisfied with the health service it received. They assume that patients who become participants BPJS JKRA get services and treatment that is different from other patients.To know the relation of patient satisfaction level of BPJS JKRA with theperformance of nurses In Inpatient Regional Meuraxa City Banda Aceh.This was an analytic descriptive study, with a total sample of 100 patients. Thesampling technique is accidental sampling. This study was conducted on 7 to 12 May 2018. The way of collecting data by distributing questionnaires. from result of research indicate patient satisfaction of BPJS JKRA pursuant to aspecttangible got $p$ value 0,023 , reliability $p$ value 0,000 , responsiveness value 0,055, empathy $p$ value 0,003, insurance $p$ value 0,035 with nurse performance at
\end{abstract}


Inpatient Hospital Meuraxa City Banda Aceh.There is a significant correlation between patient satisfaction of BPJS JKRAaccording to aspect of tangible, reliability, empathy, insurancee with nurse performance at inpatient in RSUD Meuraxa City Banda Aceh. And there is no relationship of patient satisfaction BPJS JKRA according to the aspect of responsiviness with the performance of nurses at inpatient RSUD Meuraxa City Banda Aceh.

Keywords : : patient satisfaction, nurse performance, BPJS JKRA

\section{PENDAHULUAN}

Standar kepuasan pasien di pelayanan kesehatan ditetapkan secara nasional oleh Departemen Kesehatan.Menurut Peraturan Kementrian Kesehatan Republik Indonesia Tahun 2016 tentang Standar Pelayanan Minimal untuk kepuasan pasien yaitu diatas 95\%.Bila ditemukan pelayanan kesehatan dengan tingkat kepuasaan pasien berada dibawah 95\%, maka dianggap pelayanan kesehatan yang diberikan tidak memenuhi standar minimal atau tidak berkualitas (Kemenkes RI, 2017).

Namun pada prakteknya masih ditemukan pelayanan yang tidak sesuai dengan standar pelayanan rumah sakit maupun standar keperawatan, hal tersebut dapat dilihat dari kasus yang melibatkan tenaga keperawatan seperti kurangnya kepuasan pasien terhadap pelayanan keperawatan karena dianggap pelayanan keperawatan yang diberikan tidak sesuai dalam menangani pasien.Masyarakat ingin dilayani dengan ramah, sopan, terampil, tepat waktu, dan jujur dalam pemberian informasi. Perawat harus memelihara mutu pelayanan keperawatan yang tinggi dengan cara professional dalam menerapkan pengetahuan serta keterampilan keperawatan sesuai dengan kebutuhan pasien (Siswati, 2015).

Pemerintah Aceh telah menggalakkan pengobatan gratis untuk masyarakat dengan program JKRA (Jaminan Kesehatan Rakyat Aceh) yang diintegrasikan kedalam JKN berdasarkan kerjasama antara Pemerintah Aceh dengan BPJS kesehatan yang memulai pelaksanaan program jaminan kesehatan nasional pada 1 Januari 2014 oleh Badan Penyelenggara Jaminan Sosial (BPJS) kesehatan. Menurut data yang di peroleh dari kabupaten/kota jumlah penduduk yang mempunyai jaminan/asuransi kesehatan dan Jaminan kesehatan Rakyat Aceh (JKRA) berjumlah 4.536.995 (Dinkes Aceh, 2016).

Kunjungan pasien rawat inap pengguna BPJS JKRA kelas 111 di RSUD Meuraxa sebanyak 11.575 pada bulan januari sampai desember tahun 2017. Tingkat kepuasan pasien terhadap pelayanan di RSUD Meuraxa pada tahun 2017 yaitu 74,35 termasuk dalam mutu pelayanan kategori baik $(62,51$ - 81,25) berdasarkan keseluruh instalasi pelayanan rawat inap, 
rawat jalan, laboratorium, radiologi, apotik dan fisioterapi (Profil RSUD Meuraxa, 2018). Berdasarkan observasi awal yang dilakukan di rawat inap kelas III RSUD Meuraxa sebagai penerima jasa pelayanan kesehatan BPJS JKRA, keluarga peserta mengeluh kurang puas dengan pelayanan kesehatan yang diterimanya. Mereka menganggap bahwa pasien yang menjadi peserta BPJS JKRA mendapat pelayanan dan perlakuan yang berbeda dengan pasien lain. Ada yang menyatakan perawat kurang perhatian, kurang ramah dan tidak disiplin dalam bekerja.

Berdasarkan fenomena diatas penulis tertarik melakukan penelitian yang berjudul hubungan tingkat kepuasan pasien BPJS JKRA dengan kinerja perawat di rawat inap Rumah Sakit Umum Daerah Meuraxa Kota Banda Aceh.

\section{METODE PENELITIAN}

Penelitian ini adalah penelitian bersifat deskriptif analitik dengan pendekatan cross sectional. Penelitian ini telah dilakukan di ruang rawat inap RSUD Meuraxa Kota Banda Aceh pada bulan Mei 2018 dengan populasi berjumlah 4.519 diambil enam bulan dari bulan September tahun 2017 sampai bulan Februari tahun 2018. Teknik pengambilan sampel dilakukan dengan cara non probability sampling, dengan penarikan sampling secara accidental samplingdengan jumlah sampel yaitu 100 responden. Analisa data yangdigunakan meliputi analisa univariat menghasilkan distribusi frekuensiberdasarkan presentase dari tiaptiapkarakterisitik variabel, dan analisa bivariat digunakanuntuk mengetahui hubungan antara duavariabel dengan menggunakan uji chi-square $\left(\mathrm{X}^{2}\right)$ dengan tingkat kemaknaan $95 \%(\propto=$ $0.05)$. 


\section{HASIL DAN PEMBAHSAN}

1. Analisis Univariat

Tabel 1. Distribusi Frekuensi Berdasarkan Kinerja Perawat dan Kepuasan Pasien BPJS JKRA (Bukti Fisik, Kehandala, Kepedulian, Empati Dan Jaminan di Rawat Inap RSUD Meuraxa Kota Banda Aceh

\begin{tabular}{|c|c|c|c|}
\hline No & Variabel & $\mathbf{f}$ & $\%$ \\
\hline \multirow[t]{3}{*}{1} & Kinerja Perawat & & \\
\hline & Baik & 62 & 62 \\
\hline & Kurang Baik & 38 & 38 \\
\hline \multirow[t]{3}{*}{2} & Bukti fisik & & \\
\hline & Puas & 50 & 50 \\
\hline & Kurang puas & 50 & 50 \\
\hline \multirow[t]{3}{*}{3} & Kehandalan & & \\
\hline & Puas & 46 & 46 \\
\hline & Kurang puas & 54 & 54 \\
\hline \multirow[t]{3}{*}{4} & Kepedulian & & \\
\hline & Puas & 53 & 53 \\
\hline & Kurang puas & 47 & 47 \\
\hline \multirow[t]{3}{*}{5} & Empati & & \\
\hline & Puas & 52 & 52 \\
\hline & Kurang puas & 48 & 48 \\
\hline \multirow[t]{3}{*}{6} & Jaminan & & \\
\hline & Puas & 49 & 49 \\
\hline & Kurang puas & 51 & 51 \\
\hline
\end{tabular}

Berdasarkan tabel 1 menunjukkan bahwa dari 100 responden, kinerja perawat kategori baik sebanyak 62 orang (62\%) dan kurang baik sebanyak 38 orang (38\%). Kepuasan pasien BPJS JKRA menurut aspek bukti fisik puas sebanyak 50 responden (50\%) dan kurang puas sebanyak 50 responden $(50 \%)$, kehandalan puas sebanyak 46 responden $(46 \%)$ dan kurang puas sebanyak 54 responden (54\%), kepedulian puas sebanyak 53 responden (50\%) dan kurang puas sebanyak 47 responden (47\%), empati puas sebanyak 52 responden (52\%) dan kurang puas sebanyak 48 responden (48\%), jaminan puas sebanyak 49 responden (49\%) dan kurang puas sebanyak 51 responden (51\%). 


\section{Analisis Bivariat}

Tabel 2. Hubungan Kinerja Perawat dan Kepuasan Pasien BPJS JKRA (Bukti Fisik, Kehandala, Kepedulian, Empati Dan Jaminan di Rawat Inap RSUD Meuraxa Kota Banda Aceh

\begin{tabular}{|c|c|c|c|c|c|c|}
\hline \multirow{3}{*}{ No } & \multirow{3}{*}{ Variabel } & \multicolumn{4}{|c|}{ Kinerja Perawat } & \multirow{3}{*}{$p$ value } \\
\hline & & \multicolumn{2}{|c|}{ Baik } & \multicolumn{2}{|c|}{$\begin{array}{c}\text { Kurang } \\
\text { Baik }\end{array}$} & \\
\hline & & $\mathbf{n}$ & $\%$ & $\mathbf{n}$ & $\%$ & \\
\hline \multirow[t]{3}{*}{1} & Bukti Fisik & & & & & \\
\hline & Puas & 37 & 74 & 13 & 26 & 0.023 \\
\hline & Kurang Puas & 25 & 50 & 25 & 50 & \\
\hline \multirow[t]{3}{*}{2} & Kehandalan & & & & & \\
\hline & Puas & 41 & 89 & 5 & 11 & 0.000 \\
\hline & Kurang Puas & 21 & 39 & 33 & 61 & \\
\hline \multirow[t]{3}{*}{3} & Kepedulian & & & & & \\
\hline & Puas & 38 & 72 & 15 & 28 & 0.055 \\
\hline & Kurang Puas & 24 & 52 & 23 & 48 & \\
\hline \multirow[t]{3}{*}{4} & Empati & & & & & \\
\hline & Puas & 40 & 77 & 12 & 23 & 0.003 \\
\hline & Kurang Puas & 22 & 46 & 26 & 54 & \\
\hline \multirow[t]{3}{*}{5} & Jaminan & & & & & \\
\hline & Puas & 36 & 73 & 13 & 27 & 0.035 \\
\hline & Kurang Puas & 26 & 51 & 25 & 49 & \\
\hline
\end{tabular}

\section{Pembahasan}

\section{Hubungan bukti fisik (tangible) dengan kinerja perawat}

Hasil uji statistik menunjukkan bahwa kepuasan pasien BPJS JKRA menurut aspek bukti fisik (tangible) terdapat hubungan yang signifkan dengan kinerja perawat dengan nilai $\mathrm{p}$-value $=0,023,<\alpha=0,05$. Penelitian ini sejalan dengan penelitian Nurani (2012) dalam Pertiwi (2016) menyatakan bahwa variabel yang paling berpengaruh signifikan terhadap kepuasan pasien adalah dimensi tangibles dan emphaty. Dan juga sejalan dengan penelitian dari Thamnopoulos, dkk (2011) dalam Pandu (2016) bahwa kepuasan pasien menunjukkan mereka kurang puas dengan dimensi tangibles, responsiveness dan access.

Hal tersebut sesuai dengan teori SERVQUAL dalam Pertiwi (2016) yang menyatakan bahwa bukti fisik mencakup kondisi fisik, peralatan serta penampilan petugas, karena jasa tidak dapat diamati secara langsung maka pelanggan sering kali berpedoman pada kondisi yang terlihat mengenai jasa melakukan evaluasi. Kenyataan yang berkaitan dengan hal ini mencakup objek yang sangat bervariasi, seperti penampilan petugas, karpet, tempat duduk, pencahayaan ruangan, warna dinding, brosur peralatan dan fasilitas yang 
digunakan.Bukti fisik (tangible) meliputi fasilitas fisik, yang mencangkup kelengkapan peralatan yang digunakan, kondisi sarana, serta keselarasan antara fasilitas fisik dengan jenis jasa yang diberikan (Muninjaya, 2011).

Penelitian berasumsi bahwa tingginya kepuasan pasien menurut aspek bukti fisik terhadap kinerja perawat bila terpenuhinya kebetuhan pasien/ keluarga terhadap kinerja perawat yang diharapkan.Aspek bukti fisiknya adalah penampilan perawat dan kondisi ruangan perawatan. Dalam penelitian ini kepuasan pasien BPJS JKRA menurut aspek bukti fisik masih kurang puas dengan kinerja perawat di rawat inap RSUD Meuraxa Kota Banda Aceh, ini dibuktikan dengan sebagian besar pasien BPJS JKRA yang di rawat disana mengatakan kurang puas dengan kinerja perawat yang berkinerja kurang baik, dan tentunya perlu menjadi perhatian untuk diperbaiki. Kurangya kepuasan pasien dikarenakan kondisi ruangan belum sesuai dengan harapan pasien dan juga dikarenakan fasilitas ruangan bagi pengguna BPJS JKRA berada di kelas III.

\section{Hubungan kehandalan (reliability) dengan kinerja perawat}

Hasil uji statistik menunjukkan bahwa kepuasan pasien BPJS JKRA menurut aspek kehandalan (reliability) terdapat hubungan yang signifkan dengan kinerja perawat dengan nilai $\mathrm{p}$-value $=0,000,<\alpha=0,05$. Penelitian ini sejalan dengan penelitian Putri dan Adita (2014) menyatakan bahwa terdapat hubungan yang bermakna antara reliability perawat dengan tingkat kepuasan pasien dengan $\mathrm{p}$ value $=0,000$. Dan juga sejalan dengan penelitian Mumu dan Doda (2015) dalam Pertiwi (2016) menyatakan bahwa terdapat hubungan yang signifikan antara kepuasan pasien dan dimensi kehandalan dengan nilai $\mathrm{p}$ sebesar 0,000 ( $\mathrm{p}<0,05)$. Penelitian yang dilakukan Raspati (2014) dalam Pertiwi (2016) menunjukkan bahwa ada hubungan antara mutu pelayanan kesehatan dimensi reliability dengan tingkat kepuasan pasien rawat inap Puskesmas Halmahera Kota Semarang dengan nilai p sebesar $0,008(\mathrm{p}<0,05)$.

Hal tersebut sesuai dengan teori Zeithaml dan Bitner dalam Desmi (2017) Kehandalan (reliability), kemampuan rumah sakit untuk memberikan pelayanan sesuai dengan yang di janjikan secara akurat dan terpercaya. Kinerja harus sesuai dengan harapan pasien yang berarti ketetapan waktu, pelayanan yang sama untuk semua pasien tanpa kesalahan, sikap yang simpatik dan dengan akurasi yang tinggi. Indikatornya perawat mempunyai kemampuan dalam pengobatan terhadap pasien, Diagnosis dokter/perawat 
terhadap penyakit pasien terbukti akurat, dokter/perawat/petugas administrasi datang tepat waktu dan prosedur pemeriksaan yang mudah dan cepat dalam melayani pasien.

Penelitian berasumsi bahwa semakin baik kinerja perawat akan meningkatkan kepuasan pasien begitu juga sebaliknya. Dalam penelitian ini kepuasan pasien BPJS JKRA menurut aspek kehandalan masih kurang puas dengan kinerja perawat di rawat inap RSUD Meuraxa Kota Banda Aceh, ini dibuktikan dengan sebagian besar pasien BPJS JKRA yang di rawat disana mengatakan kurang puas dengan kinerja perawat yang berkinerja kurang baik, dan tentunya perlu menjadi perhatian untuk diperbaiki. Kurangnya kinerja perawat dalam hal tersebut disebabkan kurangnya kemampuan dan keterampilan yang dimiliki perawat dalam menyelenggarakan dan memberikan pelayanan kepada pasien. Tingkat kemampuan dan keterampilan yang kurang dari tenaga kesehatan tentunya akan memeberika pelayanan yang kurang memenuhi kepuasan pasien sebagai standar penilaian terhadap kinerja perawat.

\section{Hubungan kepedulian (responsiveness) dengan kinerja perawat}

Hasil uji statistik menunjukkan bahwa kepuasan pasien BPJS JKRA menurut aspek kepedulian (responsiveness) tidak terdapat hubungan yang signifkan dengan kinerja perawat dengan nilai $\mathrm{p}$-value $=0,055,>\alpha=0,05$. Penelitian ini tidak sejalan yang dilakukan Putri dan Adita (2014) menyatakan bahwa terdapat hubungan yang bermakna antara responsiveness (kepedulian) perawat dengan tingkat kepuasan pasien di ruang rawat Achmad Mochtar Bukittinggi 2014 dengan p value $=0,015$.

Hal tersebut tidak sesuai dengan teori Zeithaml dan Bitner dalam Desmi (2017) yang menyatakan kepedulian (responsiveness) yaitu suatu kemauan untuk membantu dan memberikan pelayanan yang cepat (responsif) dan tetap kepada pasien, dengan menyampaian informasi yang jelas. Membiarkan pasien menunggu tanpa adanya suatu alasan yang jelas menyebabkan persepsi yang negatif dalam kualitas pelayanan.Pengaruh kepedulian terhadap kepuasan pasien yaitu hubungan kepedulian dengan kepuasan pasien adalah kepedulian mempunyai pengaruh positif terhadap kepuasan pasien.

Penelitian berasumsi bahwa kepedulian perawat dalam menanggapi keluhan pasien tergantung kepada perawat tersebut, karena dengan kinerja yang baik pasien akan merasa terpenuhi kebutuhannya seperti siap, cepat dan tepat perawat memberikan tindakan keperawatan dan tanggap atas keluhan pasien, sehingga pada akhirnya mereka merasa puas 
dengan apa yang didapatkan dalam pelayanan keperawatan. Dalam penelitian ini kepuasan pasien BPJS JKRA menurut aspek kepedulian sudah puas dengan kinerja perawat di rawat inap RSUD Meuraxa Kota Banda Aceh, ini dibuktikan dengan sebagian besar pasien BPJS JKRA yang di rawat disana mengatakan puas dengan kinerja perawat yang berkinerja baik dan hal ini dikarenakan perawat sudah memenuhi kebutuhan pasien akan pelayanan yang dinginkan.

\section{Hubungan empati (empaty) dengan kinerja perawat}

Hasil uji statistik menunjukkan bahwa kepuasan pasien BPJS JKRA menurut aspek empati (empaty) terdapat hubungan yang signifkan dengan kinerja perawat dengan nilai pvalue $=0,003,<\alpha=0,05$. Penelitian ini sejalan dengan penelitian Yuniarti (2015) dalam Pertiwi (2016) menyatakan bahwa ada hubungan antara kualitas pelayanan rumah sakit pada dimensi emphaty dengan tingkat kepuasan pasien BPJS dengan nilai p sebesar 0,000 $(\mathrm{p}<0,05)$. Penelitian ini juga sejalan dengan penelitian Nurani (2012) dalam Pertiwi (2016) menyatakan bahwa variabel yang paling berpengaruh signifikan terhadap kepuasan pasien adalah dimensi tangibles dan emphaty.

Hal tersebut sesuai dengan teori Zeithaml dan Bitner dalam Desmi (2017) Empati (empathy) yaitu memberikan perhatian yang tulus dan bersifat individual atau pribadi memiliki pengertian dan pengetahuan tentang pasien, memahami kebutuhan pasien secara sefesifik, serta memiliki waktu pengoperasian yang nyaman bagi pasien yang di berikan kepada para pasien dengan berupaya memahami keingian pasien.

Penelitian berasumsi bahwa semakin baik kinerja perawat akan meningkatkan kepuasan pasien begitu juga sebaliknya. Dalam penelitian ini berarti kepuasan pasien BPJS JKRA menurut aspek empati masih kurang puas dengan kinerja perawat di rawat inap RSUD Meuraxa Kota Banda Aceh, ini dibuktikan dengan sebagian besar pasien BPJS JKRA yang di rawat disana mengatakan kurang puas dengan kinerja perawat yang berkinerja kurang baik dan tentunya perlu menjadi perhatian untuk diperbaiki. Kurangnya kinerja perawat dalam hal tersebut disebabkan kurangnya perhatian yang diberikan oleh perawat kepada pasien.Perawat yang memiliki kinerja baik, namun melahirkan ketidak puasan pasien disebabkan karena pasien ingin mendapatkan perhatian penuh dan khusus dari perawat. 


\section{Hubungan jaminan (insurance) dengan kinerja perawat}

Hasil uji statistik menunjukkan bahwa menurut kepuasan pasien BPJS JKRA aspek jaminan (insurance) terdapat hubungan yang signifkan dengan kinerja perawat dengan nilai p-value $=0,035,<\alpha=0,05$. Penelitian ini sejalan dengan penelitian Desmi (2017) yaitu berpengaruh signifikan terhadap kepuasan pasien pengguna BPJS dimensi jaminan pada Puskesmas Sungai Aur Kabupaten Pasaman Barat sebesar 0,097 atau 9,7\%. Semakin baik insurance maka akan meningkatkan kepuasan pasien.

Hal tesebut sesuai dengan teori Pertiwi (2016) Yaitu berkaitan dengan kemampuan, pengetahuan, ketrampilan staf dalam menangani setiap pelayanan yang diberikan sehingga mampu menumbuhkan kepercayaan dan rasa aman pada pelanggan. Jaminan (insurance) merupakan mencakup pengetahuan, kemampuan, kesopanan, dan sifat dapat dipercaya yang dimiliki para staf : bebas dari bahaya, resiko atau keragu-raguan. Pada saat persaingan sangat kompetitif, anggota perusahaan harus tampil lebih kompeten, artinya memiliki pengetahuan dan keahlian di bidang masing-masing.Faktor keamanan, yaitu memberikan rasa aman dan terjamin kepada pelanggan merupakan hal yang penting pula).

Penelitian berasumsi bahwa tingginya kepuasan pasien (menurut aspek jaminan) dipengaruhi oleh kinerja perawat, semakin baik kinerja perawat semakin tinggi kepuasan pasien begitu juga sebaliknya. Dalam penelitian ini berarti kepuasan pasien BPJS JKRA menurut aspek jaminan masih kurang puas dengan kinerja perawat di rawat inap RSUD Meuraxa Kota Banda Aceh, ini dibuktikan dengan sebagian besar pasien BPJS JKRA yang di rawat disana mengatakan kurang puas dengan kinerja perawat yang berkinerja kurang baik dan tentunya perlu menjadi perhatian untuk diperbaiki. Kurangnya kinerja perawat dalam hal tersebut disebabkan kurangnya kenyamanan dan ketenangan yang dirasakan pasien saat menerima pelayanan, serta dukungan dan komunikasi dari pemberi pelayanan saat melakukan perawatan.

\section{KESIMPULAN}

Berdasarkan hasil penelitian dapat disimpulkan pada analisis bivariate ada hubungan antara bukti fisik, kehandalan, kepedulian,empati dan jaminan dengan kinerja perawat karena $p$ value $<0.05$.

\section{SARAN}

Saran yang dapat diberikan dari hasil pembahasan yang telah dilakukan peneliti adalah: 


\section{Bagi Manajemen Rumah Sakit Umum Daerah Meuraxa Kota Banda Aceh}

a. Saran bagi manajemen rumah sakit dalam tangibles (bukti fisik) yaitu perlunya meningkatkan indikator gedung Rumah Sakit berupa ruang perawatan menjadi bagus serta bersih.

b. Saran bagi manajemen rumah sakit dalam Reliability (kehandalan), perlunya meningkatkan indikator memberikan layanan yang tepat dan benar sesuai dengan keluhan penyakin pasien.

c. Saran bagi manajemen rumah sakit dalam Responsiveness (kepedulian), perlunya meningkatkan indikator perawat selalu ada dalam memenuhi keluhan dan kebutuhan pasien sesuai jadwal berupa meningkatkan pengontrolan terhadap petugas yang tidak tepat waktu dalam melaksanakan jadwal tugasnya.

d. Saran bagi manajemen rumah sakit dalam Empathy (empati), perlunya meningkatkan indikator perawat dalam memberikan perhatian yang khusus terhadap pasien berupa petugas meningkatkan kemauan untuk melakukan pendekatan kepada pasien yang susah diatur dan menanyakan keadaan pasien setiap kali pertemuan.

e. Saran bagi manajemen rumah sakit dalam Insurance (jaminan), perlunya meningkatkan indikator perawat untuk dapat menumbuhkan rasa percayapasien atas tindakan keperawatan, aman dan tenang dengan cara memberikan kata-kata harapan kepada pasien untuk cepat sembuh dan memberikan sugesti positif kepada pasien.

2. Bagi Perawat Rumah Sakit Umum Daerah Meuraxa Kota Banda Aceh

Dapat mendorong upaya-upaya dalam menyusun standar-standar pelayanan keperawatan yang dapat dijadikan rujukan dalam melaksanakan kegiatan pemberian layanan keperawatan dan meningkatkan kinerja perawat sehingga dapat terpenuhi kepuasan pasien atas kinerja perawat.

\section{Bagi Pendidikan Kesehatan}

Hasil penelitian ini diharapkan dapat dijadikan sebagai bahan referensi tambahan dalam memberikan masukan bagi pengembangan pengetahuan serta menjadi evidence khususnya dalam pengajaran diperkuliahan yang berhubungan dengan kinerja perawat, dan juga diharapkan untuk dapat melakukan penelitian lain pada responden, lokasi penelitian, dan juga menambahkan variabel yang berbeda pada penelitian berikutnya, dengan demikian dapat menghasilkan temuan yang baru. 


\section{Bagi Pemerintah}

Memonitoring dan mengevaluasi kinerja pelayanan rumah sakit khususnya perawat di setiap instalasi rumah sakit pemerintahan. Dan dapat memeningkatkan fasilitas bagi pengguna BPJS JKRA.

\section{DAFTAR PUSTAKA}

Desmi. (2017). Pengaruh Tangibles, Empaty, Reliability, Responsiveness dan Assurance Jasa Kesehatan Terhadap Kepuasan Pasien Pengguna BPJS Pada Puskesmas Sungai Aur Kabupaten Pasaman Barat. Sumatera Barat : Jurnal STKIP PGRI

Dinas Kesehatan Aceh,(2016). Profil Kesehatan Provinsi Aceh Tahun 2015. Banda Aceh: Dinas Kesehatan Aceh

Dinas Kesehatan Kota Banda Aceh.(2017). Profil kesehatan Kota Banda Aceh Tahun 2016. Banda Aceh: Dinas Kesehatan

Firdaus, Fidela. (2015). Evaluasi Kualitas Pelayanan Terhadap Kepuasan Pasien Rawat Jalan Peserta BPJS di RSUD Panembahan Senopati Bantul. Yogyakarta: TesisUniversitas Muhamadiyah

Kementrian Kesehatan RI. (2017). Profil Kesehatan Indonesia 2016. Jakarta: Kementerian Kesehatan RI

Kemenkes RI. (2017) .Situasi Tenega Keperawatan Indonesia. Jakarta Selatan: Pusat danInformasi Kemenkes RI

Muninjaya, Gde AA. (2011). manajemen Mutu Pelayanan Kesehatan. Jakarta: EGC

Notoatmodjo,S. (2012). Metodologi Penelitian Kesehatan. Jakarta: Rineka CiptaPandu, Widyana Adirta,. 2016. Hubungan Kualitas Pelayanan Perawat Dengan Tingkat Kepuasan Pasien Rawat Inap Di RSUD dr. R. Goeteng Taroenadibrata Purbalingga Tahun 2016. Purwokerto: Skipsi Universitas Muhammadiyah.

Pertiwi, ilahi puji. (2016). Hubungan Kepuasan Pasien Penggunaa BPJS TerhadapKualitas Pelayanan Kesehatan Di Puskesmas Nagrak Sukabumi Tahun 2016. Jakarta: Skripsi Universiatas Isalmi Negeri Syarif Hidayatullah

Profil Rumah sakit Daerah Umum Meuraxa tahun 2017

Siswati, Sri. (2013). Etika dan Hukum Kesehatan dalam Perspektif Undang-Undang Kesehatan. Jakarta: PT Rajagrafindo Persada 